\title{
A pluralidade e abrangência da pesquisa em Educação Física e Esporte em destaque na RBEFE
}

O número 1, do volume 28, da Revista Brasileira de Educação Física e Esporte - RBEFE - vem precedido, mais uma vez, pela disponibilização dos artigos no sistema "ahead of print". Seis artigos foram disponibilizados, incluindo Artigos Originais e Ensaios. Alguns destes artigos já fazem parte do presente número. Reforçando o comprometimento da RBEFE em possibilitar a disseminação do conhecimento científico de nossa área considerando a reconhecida pluralidade da Educação Física e do Esporte no que tange à produção do conhecimento, o número 1 da RBEFE de 2014 traz artigos originais de qualidade nas três subáreas, Biodinâmica, Sociocultural, Pedagógica e Comportamental. No tocante aos ensaios, dois elegantes textos são disponibilizados e conduzem o leitor desde a dimensão do "Imaginário do lazer $e$ do lúdico" à reflexão dos desafios e produçáo do conhecimento na área da genética e performance esportiva. A Pluralidade e abrangência se revelam não somente no que concernem as diferenças entre as subáreas, mas também no contexto "intra-área". Destaco a qualidade dos artigos publicados na seção "Biodinâmica", contemplando pesquisas originais que abrangem desde a "Análise da validade dos parâmetros absolutos e relativos para $O$ cálculo da potência anaeróbia no RAST" e o "Efeito da suplementação de creatina, associada ou não ao treinamento de força, sobre a peroxidação lipídica em mulheres idosas", passando pela publicaçấo dos artigos "Efeito de quatro dias consecutivos de jogos na potência muscular, estresse e recuperação percebida em jogadores de futsal", "Aptidão fisica relacionada à saúde de adolescentes participantes de programa esportivo", "Validação de uma bateria de testes para avaliação da autonomia funcional de adultos com lesão na medula espinhal", "Análise do desempenho em atletas de elite no 'Iroman' Brasil entre os anos de 2003 a 2010". $\mathrm{Na}$ seção "Sociocultural", tem destaque o "Kung Fu" no Brasil na perspectiva dos mestres pioneiros: problemas e perpectivas no uso da história oral como instrumental de análise", o "Bem estar do trabalhador docente de educação física da região sul do Brasil de acordo com os ciclos vitais", "Momentos iniciais da Educação Física em Goiás", e a discussão da "Eficácia organizacional na percepção do presidente da Federação Portuguesa de Canoagem". Na subárea Pedagógica e Comportamental, os títulos "Participação dos pais na carreira das atletas femininas de ginástica artística: a perspectiva dos técnicos", "Estudo da quantidade de jogadores em jogos reduzidos de handebol: mudança na dinâmica técnica e tática", e "Educação física no ensino médio: desenvolvimento de conceitos e da aptidão fisica relacionados à saúde", completam o Número 1 de 2014, e asseguram a publicação de qualidade, enquanto garantem, ao mesmo tempo, a pluralidade do conteúdo publicado na RBEFE.

\section{Prof. Dr. Alexandre Moreira}

Blog da RBEFE - http://rbefe.blogspot.com.br 